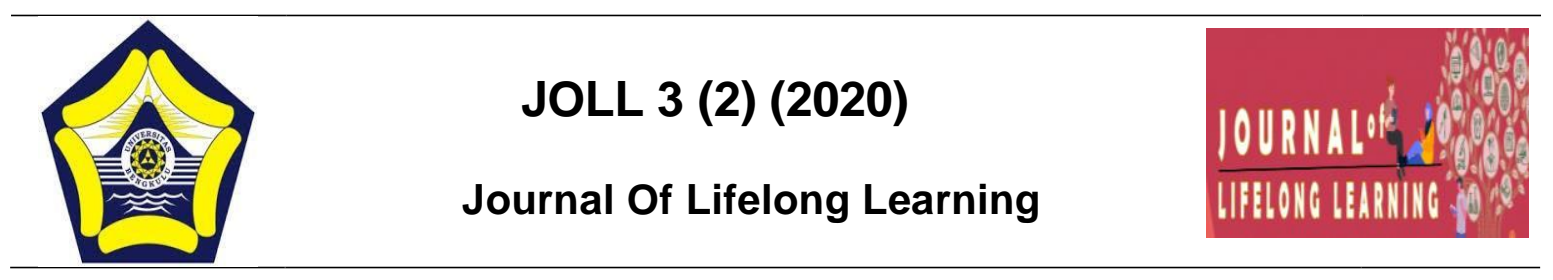

PENDIDIKAN KETERAMPILAN PENGUSAHA KULINER

\author{
Mujiono ${ }^{1}$, Sofino $^{2}$, Ilham Abdullah ${ }^{3}$ \\ ${ }^{1}$ Mujiono, Universitas Bengkulu, Indonesia, mujio1701@gmail.com \\ ${ }^{2}$ Sofino, Universitas Bengkulu, Indonesia, sofino@unib.ac.id \\ ${ }^{3}$ Ilham Abdullah, Universitas Bengkulu, Indonesia, ilhamabdullah@unib.ac.id
}

\begin{abstract}
The purpose of this study is to describe the success of the Solo 99 super meatball culinary business in the city of Bengkulu, as many as three subjects in this study. This research is a qualitative research. Data collection techniques using interview, observation and documentation. Data analysis techniques include data reduction, data presentation and conclusion drawing. Checking the validity of the data using triangulation techniques. The research results show that first, there is a form of success obtained during running a meatball culinary business in the form of assets such as shop houses, boarding houses, cars and motorcycles as well as gaining popularity and benefits of building an economic system in the vicinity. Second, the acquisition of meatballs culinary entrepreneurship skills education is obtained by the owner by self-taught by learning from experience, actively asking and paying attention and diligently reading books and looking for info from social media. Third, the effort to develop innovative businesses is to make new innovations in food and beverage menus and the process of making meatball balls so that they can be promoted. Fourth, the obstacle faced is the price of raw materials going up and down or unstable. Fifth, the solution made to deal with existing problems is by reducing the portion of meatballs that are sold but not too much.
\end{abstract}

Keywords: Success, Business, Culinary, Meatballs

C2020 DeptofNonformalEducationUNIB ISSN : 2715-9809

\title{
$\square$ Addresscorrespondence:
}

Jl.W.R.Supratman,KandangLimun,MuaraBangkaHulu, KotaBengkulu,Bengkulu38371 


\section{PENDAHULUAN}

Pendidikan merupakan suatu sistem yang memiliki berbagai aspek yaitu, aspek legalitas atau hukum, historis, psikologis, budaya, sosiologis, dan ekonomi. Berdasarkan UU No.20 Tahun 2003 Pasal 1 tentang Sistem Pendidikan Nasional bahwa :

Pendidikan adalah usaha sadar dan terencana untuk mewujudkan suasana belajar dan proses pembelajaran agar peserta didik secara aktif mengembangkan potensi dirinya untuk memiliki kekuatan spiritual keagamaan, pengendalian diri, kepribadian, kecerdasan, akhlak mulia, serta keterampilan yang diperlukan dirinya, masyarakat, bangsa dan negara.

Pendidikan nasional sangat berperan dalam pembangunan manusia seutuhnya. Melalui pendidikan dapat mewujudkan manusia yang berakhlak mulia, berkarakter produktif dan berdaya saing, sehingga dapat meningkatkan kemakmuran dan kesejahteraan rakyat sesuai dengan pembukaan UUD 1945.

Kewirausahaan adalah padanan kata dari entrepreneurship dalam bahasa Inggris, unternehmer dalam bahasa Jerman, ordernemer dalam bahasa belanda. Adapun di Indonesia diberi nama kewirausahaan. Kata entreprende yang berarti petualang, pengambil risiko, kontraktor, pengusaha (orang yang mengusahakan suatu pekerjaan tertentu), dan pencipta yang menjual hasil ciptaanya (Muhammad Anwar 2014: 2-4).

Suyanto (2010;179) keberhasilan usaha industri kecil dipengaruhi oleh berbagai faktor. Kinerja usaha perusahaan merupakan salah satu tujuan dari setiap pengusaha. Kinerja usaha industri kecil dapat diartikan sebagai tingkat keberhasilan usaha suatu perusahaan dapat dilihat dari berbagai aspek, seperti: kinerja keuangan dan image perusahaan. Menurut Glancey dalam Sony Heru Priyanto (2003:73) wirausaha yang memiliki kemampuan mengambil keputusan yang superoir akan dapat meningkatkan perfomansi usaha seperti peningkatan profit dan pertumbuhan usaha.

Faktor-faktor yang mempengaruhi keberhasilan usaha dapat diketahui dari dua faktor yaitu faktor internal dan faktor eksternal. Faktor internal yang diantaranya yaitu kualitas SDM, penguasaan, organisasi, struktur organisasi, sistem manajemen, partpisipasi, kultur/budaya bisnis, kekuatan modal, jaringan bisnis dengan pihak luar, dan tingkat entrepreneurship. Faktor eskternal dapat dibagi menjadi dua yaitu faktor pemerintah dan non pemerintah. Faktor pemerintah diantaranya, kebijakan ekonomi, birokrat, politik, dan tingkat demokrasi. Faktor non pemerintah yaitu; sistem perekonomian, sosio-kultur budaya masyarakat, sistem perburuan dan kondisi perburuan, kondisi infrakstruktur, tingkat pendidikan masyarakat, dan lingkungan global (Tulus Tambunan 2002:14).

Pendidikan Non Formal berfungsi sebagai pelengkap dan pengganti pendidikan formal karena tidak semua kebutuhan pendidikan masyarakat dapat terpenuhi dengan adanya pendidikan Non Formal sangat terbatas dan membatasi sehingga kehadiran pendidikan Non Formal sangat diperlukan mutlak sangat dibutuhkan. 
Dengan adanya Pendidikan Non Formal masyarakat dapat belajar meningkatkan kemampuannya. Jika masyarakat telah memiliki kemampuan dan tingkatan kemudian seiring berjalannya waktu dapat dikembangkan sesuai keinginannya (passion). Maka dari itu masyarakat dapat memulai sebuah kewirausahaan.

Usaha kecil merupakan ekonomi rakyat yang berskala kecil dengan bidang usaha yang secara mayoritas berdiri sendiri, merupakan kegiatan usaha yang perlu dilindungi oleh pemerintah untuk mencegah dari persaingan usaha yang tidak sehat. Salah satu bentuk dari usaha kecil adalah Bakso Super Solo 99 Kota Bengkulu.

Menurut Andarwulan, pakar teknologi pangan dari Institut Pertanian Bogor bakso merupakan produk gel dari protein daging, baik dari daging sapi, ayamikan, maupun udang dan dibentuk bulatan-bulatan kemudian direbus. Selain protein hewani, aneka daging itu juga mengandung zat-zat gizi lainnya, termasuk asam amino esensial yang penting bagi tubuh (dalam Cahyadi, 2009:292-293).

Kriteria UMKM

\begin{tabular}{|l|c|c|c|}
\hline No. & $\begin{array}{c}\text { Bentuk } \\
\text { Usaha }\end{array}$ & $\begin{array}{c}\text { Kategori } \\
\text { Aset }\end{array}$ & $\begin{array}{c}\text { Kriteria } \\
\text { Omset }\end{array}$ \\
\hline 1. & $\begin{array}{c}\text { Usaha } \\
\text { Mikro }\end{array}$ & Maks.50 jt & Maks.300 jt \\
\hline 2. & Usaha & $>50 \mathrm{Jt}-500$ & $>300 \mathrm{Jt}-$ \\
& Kecil & jt & $2,5 \mathrm{M}$ \\
\hline 3. & Usaha & $>500 \mathrm{Jt} .-$ & $>2,5 .-50 \mathrm{M}$ \\
& Menengah & $10 \mathrm{M}$ & \\
\hline
\end{tabular}

Kondisi UMKM yang ada di provinsi Bengkulu Pada tahun 2017 total UMKM Rp. 4.050.884.511.027. Sehingga
Banyak usaha yang muncul dan berkembang saat ini. Salah satu usaha yang menarik untuk dijalankan yaitu dalam bidang bisnis usaha kuliner bakso. Usaha kuliner bakso ini adalah usaha yang memanfaatkan promosi dan berdasarkan kebutuhan masyarakat. Untuk menjalankan usaha kuliner bakso ini diperlukan keterampilan dalam usaha kuliner bakso dan inovasi dalam pengembangan usahanya. Dengan memanfaatkan ruko sebagai tempat penjualannya.

Berdasarkan perkembangan usaha bakso tersebut, maka penulis tertarik melakukan penelitian dengan judul "Keberhasilan Usaha Kuliner Bakso Super 99 Solo Kota Bengkulu”.

\section{METODE}

Dalam penelitian ini diarahkan pada upaya menemukan teori yang bersifat deskriptif kualitatif karena permasalahan yang ada dalam penelitian ini menguraikan, menggambarkan dan menelaah suatu kasus secara lebih detail tentang keberhasilan usaha kuliner bakso super 99 Solo kota Bengkulu. Dalam penelitian ini digunakan peneliti sebagai instrumen utama dalam penelitian kualitatif, peneliti berpartisipasi secara tidak langsung hanya menganalisa, mewawancarai mengobservasi langkahnya yaitu menganalisa data yang ada.

Dalam penelitian ini yang menjadi subjek penelitian yaitu pemilik usaha bakso yang bernama Sarwono, Karyawan bakso Agus Rahman dan pelanggan bakso Zamari. Teknik pengumpulan data menggunakan wawancara, observasi dan dokumentasi. Wawancara merupakan suatu pertemuan dua orang untuk bertukar 
informasi dan ide melalui tanya jawab, sehingga dapat dikonstruksikan makna dalam suatu topik tertentu.

Dalam penelitian ini, peneliti sebagai pewawancara (interviewer) akan melakukan wawancara secara langsung dengan pihak yang diwawancarai (interviewer) yaitu pemilik bapak Sarwono, karyawan Agus Rahman dan pelanggan Zamari alasan peneliti menggunakan teknik ini adalah peneliti bisa bertatap muka langsung dengan responden. Agar responden dapat menyampaikan jawaban apa yang ditanyakan oleh peneliti.

Dalam penelitian ini penulis menggunakan teknik observasi tidak langsung (non participant observation) yaitu dimana observer tidak ikut dalam kehidupan orang yang akan diobservasi, dan secara terpisah berkedududkan selaku pengamat.

Dokumentasi merupakan Catatan peristiwa yang sudah berlalu. Dokumen bisa berbentuk tulisan, gambar, atau karya-karya monumental dari seorang. Dokumen yang berbentuk tulisan misalnya catatan harian, sejarah kehidupan (life histories), cerita, biografi, peraturan, kebijakan

Dokumentasi dalam penelitian ini ditujukan untuk mengumpulkan data langsung dari tempat penelitian, berupa sertifikat yang dimiliki usaha, laporan keuangan, perkembangan usaha, dan dokumen-dokumen lainnya yang dapat didokumentasikan untuk menunjang penelitian.

Kemudian untuk menguji validitas data, peneliti menggunakan teknik triangulasi. Menurut Sugiyono (2013:273) menjelaskan bahwa: Triangulasi dalam pengujian kredibilitas ini diartikan sebagai pengecekan data dari berbagai sumber dengan berbagai cara, dan berbagai waktu. Dengan demikian dapat triangulasi sumber, teriangulasi teknik dan triangulasi waktu.

\section{HASIL DAN PEMBAHASAN.}

1. perolehan pendidikan keterampilan berwirausaha yang dilakukan pengelola usaha kuliner bakso super 99 Solo kota Bengkulu.

Hasil temuan peneliti terkait dengan perolehan pendidikan keterampilan berwirausaha yang dilakukan pengelola usaha kuliner bakso antara lain :

a. Pemilik usaha kuliner bakso super 99 Solo yaitu pak Sarwono hanya menyelesaikan pendidikan hingga SMA.

b. Sarwono tidak pernah mengikuti pelatihan kewirausahaan.

c. Sarwono mendapatkan keterampilan berwirausaha dari sahabatnya mas Budianto, pemilik usaha bakso juga di kota Solo Jawa Tengah.

d. Sarwono mendapatkan pendidikan keterampilan berwirausaha bakso ini sejak tahun 2000.

e. Pendidikan keterampilan berwirausaha bakso ini di dapatkan Sarwono di Jawa Tengah. Tepatnya di kota Solo pak Sarwono dapat keterampilan berwirausaha bakso dari sahabatnya. 
keterampilan (skill) yang diperlukan seorang entrepreneur untuk menujang keberhasilan bisnis menurut Eddy (2009) adalah sebagai berikut :

1. Technicall Skiil, yaitu keterampilan yang diperlukan untuk melakukan tugas-tugas khusus, seperti sekretaris, akuntan-auditor, dan ahli gambar.

2. Human relations skill, yaitu keterampilan untuk memahami, mengerti, berkomunikasi, dan berelasi dengan orang lain dalam organisasi.

3. Conceptual skill, yaitu keterampilan personal untuk berpikir abstrak, untuk mendiagnosis dan untuk menganalisis situasi yang berbeda, dan melihat situasi luar.

4. Decision making skill, yaitu keterampilan untuk merumuskan masalah dan memilih cara bertindak yang terbaik untuk memecahkan masalah tersebut.

5. Time management skill, yaitu keterampilan dalam menggunakan dan mengatur waktu se-efisien dan se-produktif mungkin.

6. Individual skill and attitudes, yaitu keterampilan dan sikap individu.

7. Knowledge of business, yaitu pengetahuan tentang bisnis yang akan dimasuki.

8. Estabilishment of goal, yaitu kemantapan dalam menentukan tujuan yang akan dimasuki.

9. Take advantages of the apportunities, yaitu keunggulan dalam menemukan peluang bisnis.
10. Adapt to the change, yaitu kemampuan untuk beradaptasi dengan perubahan.

11. Minimize the threats to business, yaitu kemampuaan untuk meminimalkan ancaman terhadap perusahaan.

Berdasarkan penjelasan oleh ahli diatas, peneliti dapat simpulkan bahwa skill atau keterampilan yang diperlukan bagi seorang pengusaha adalah hal-hal yang sudah dijelaskan diatas.

Edwin B.Flippo (1972:2) dalam Rufran (2013) buku bahan ajar manajemen pelatihan mengemukakan bahwa :

"Training is the act of increasing the knowledge and skill of an employee for doing a particular job" (pelatihan adalah tindakan meningkatkan pengetahuan dan keterampilan seorang pegawai untuk melaksanakan pekerjaan tertentu).

Berdasarkan hasil temuan peneliti di lapangan dan teori-teori yang ada, dapat disimpulkan bahwa perolehan pendidikan keterampilan berwirausaha yang dilakukan pengelola yang memiliki latar belakang pendidikan tamatan SMA bpk Sarwono sudah memiliki banyak pengalaman kerja, yang dimulainya dari tamat SMA. Selama ini ia tidak mengikuti pelatihan kewirausahaan, namun hanya berdasarkan pengalaman yang ia lalui yang membuatnya belajar tentang kewirausahaan. Pada tahun 2000 ia mulai bekerja dan membuka usaha bakso sendiri, Kemudian untuk menunjang pengetahuannya dengan cepat, Sarwono juga sering mencari informasi mengenai bakso dan wirausaha melalui sosmed dan buku. 


\section{KESIMPULAN}

Dari hasil di lapangan tentang keberhasilan usaha kuliner bakso super 99 Solo studi kasus J1. WR. Supratman No 14 RT 1 RW 1 UNIB Belakang kelurahan Kandang Limun Kecamatan Muara Bangkahulu kota Bengkulu, berdasarkan masalah, tujuan penelitian, hasil penelitian dan pembahasan maka dapat disimpulkan bahwa :

Perolehan pendidikan keterampilan berwirausaha yang dilakukan pengelola yaitu belajar dari pengalaman bekerja di usaha bakso sahabatnya mas Budianto. Dari sana ia rajin dan aktif bertanya maupun memperhatikan cara berwirausaha bakso yang baik. Untuk menunjang cepat pengetahuannya, ia juga antusias mencari pengetahuan melalui sosmed dan buku.

\section{REFERENSI}

Anwar, Muhammad. 2017. Pengantar Kewirausahaan Teori dan Aplikasi. Jakarta: PT Kharisma Putra Utama.

Baye, M. (2011). Managerial Economic and Business Strategy (Eight Edition). New York: McGraw-Hill.

Cahyadi. W. (2009). Analisis \& Aspek kesehatan bahan tambahan pangan. Jakarta. PT. Bumi Aksara.

Kotler P., \& Amstrong G. (2012). Principle of Marketing. New Jersey: Pearson.

Philip Kotler dan Amstrong, prinsip-prinsip pemasaran, Ed 12, Jilid 1, (Jakarta: Penerbit Erlangga, 2008), h. 278

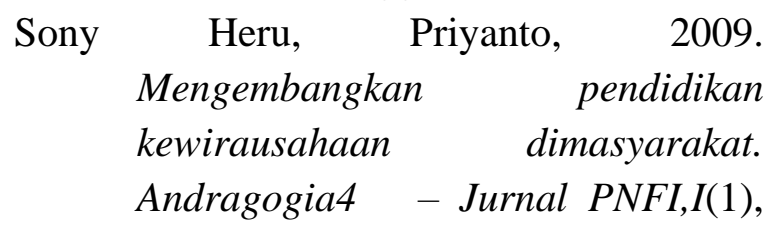

hal. 57-82. http://andragogiap2pnfisemarang.org / diakses 15 Oktober 2018).

Tambunan, T. 2002. Perdagangan Internasional dan Neraca Pembayaran: Teori dan Temuan Empiris. Jakarta:LP3ES.

Zulkarnain, Rufran. 2013. Bahan Ajar Manajemen Pelatihan. Bengkulu 